\title{
The Knives Man: A Clinical Study
}

\author{
Henrique Guilherme Scatolin \\ PUC-SP (Pontificate Catholic University of São Paulo), São Paulo, Brazil
}

\begin{abstract}
Beginning with the Freudian concept about the ritual in obsessional neurosis, the purpose of this article is to focus on the ritual to hide knifes as a particular and individual religion of an obsessive neurotic. From the psychopathology legated by Freud, the author analyzes, succinctly, the clinical case of a neurotic that hides knifes since his childhood. Over the results, the knife is pointed out as a symbolic representative of paternal sadistic penis which incorporation made possible the male identification of this patient, leaving the traces of anal eroticism exposed to the ghost of his homosexuality. It is concluded that any obsessive act expresses the ambivalence present in the neurotic psychic dynamics, like the desire and fear, the love and hate, such as his self-destructive impulses.
\end{abstract}

Keywords: obsessional neurosis, obsessive ritual, death impulse, ambivalence

\section{A Brief History About the Obsessive Ritual Concept in Freudian Theory}

The understanding of obsessive ritual on Freudian work presents its first theoretical traces in 1895, in the text Obsessions and Phobias: Its Psychic Mechanism and its Etiology. Still in the perspective of neurosis traumatic theory, Freud (1895) stated that in obsessions "The original representation... was replaced by acts or impulses that originally served as relief measures or as protective procedures" (p. 169). In these relief measures or protective procedures, the obsessive ritual is found, a symptom considered as a replacement representation of the traumatic event.

During the term of the neurosis traumatic theory (period from 1892 to 1897), Freud (1896) highlights that, in obsessive neurosis, "The subsequent period, the disease, is characterized by the return of repressed memories - that is, by the defense failure" (p. 170). He considers the obsessive ritual as a consequence of the defense failure; that is, as a result of the repressed traumatic memories return. At this time, still under the pillars of neurosis traumatic theory, the obsessive ritual (like other obsessive symptoms) is understood as a compromise formation that represents the repressed return. Consequently, the ego, while repulsing the derivatives of the initially repressed memory (traumatic memory), creates, in this defensive struggle, symptoms that can be classified as secondary defenses, such as the protective actions. These actions include: penitential measures, precautionary measures, oppressive ceremonials, numbers observation, and other actions.

By abandoning the neurosis traumatic theory in 1897, stating that, "I do not believe in my neurotic" (letter 69, p. 309), Freud only returns to the ceremonial act study in 1907, in the text Obsessive Acts and Religious Practices.

In this text, Freud (1907) stresses that "The internal understanding of neurotic ceremonial can, by analogy, stimulate us to establish inferences about psychological processes of religious life" (p. 110). He establishes an analogy between the neurotic ceremonial acts and the religious practices: while in neuroses, the instincts nature

Henrique Guilherme Scatolin, Master, PUC-SP (Pontificate Catholic University of São Paulo). 
is exclusively sexual; in religion, these instincts come from selfish sources. The neurotic ceremonial acts are understood as small changes in certain everyday acts, in small additions, restrictions or arrangements that must be performed in the same order. All ceremonial or obsessive acts present an individual character while the religious obsessive acts are carried out in a collective character. In other words, the neurotic ceremonial is carried out as if he was obeying tacit laws. The consciousness that determines its realization, and the anxiety that can arise if something does not go as expected, that grants the ceremonial act its character of sacred act. During the ritual, any interruption can lead the neurotic to certain anguish.

According to Freud (1907), "all details of the obsessive acts have a sense, which serve to important personality interests... They do it in two ways: through direct or symbolic representation and it may, therefore, be historically or symbolically interpreted" (p. 100). That is, the obsessive acts express the obsessive (repressed) wishes, because all obsessive acts details have a sense and can be interpreted. In the rituals, the neurotic symbolically expresses unconscious reasons and ideas.

In addition, the repression failure, pointed out in 1896, is reiterated in this article. For Freud (1907), "The repression process that leads to the obsessional neurosis must be regarded as a process that only gets partial success, being constantly under the threat of a failure" (p. 114). In this failure, there are numerous obsessive symptoms, comprising these ceremonial acts.

A good example of obsessive symptom to be mentioned is the case of the young lawyer Ernest Lanzer, the Rats Man. In this patient it is the repressed hate towards his father figure (as well as regarding his lady) that motivates him in his rituals. In his protective measures, repressed hostile impulses are found; such as the act of removing a stone from the road so that his lady did not have an accident. This protective measure can be considered a symbolic act that expresses all of this patient's unconscious hostility, since moving the stone is an act that neutralizes, annuls the obsessive thinking that something could happen to his lady.

After publishing the clinical case of the Rats Man, Freud returns to the study on ceremonial acts in Totem and Taboo, in 1913. In this article, while pointing out certain prohibitions present in primitive tribes and comparing them with the neurotic mental life, Freud (1913) postulates that, "The most evident and striking concordance pointed between the neurotic obsessive prohibitions and the taboos is that these prohibitions are equally devoid of reason, being similarly mysterious in its origins. Having arisen in certain unspecified moment, they are forcibly maintained by an irresistible fear" (p. 44). Obsessive actions do not have any sense to who practices them. But all ritual is surrounded by a certain conscious fear that any person of the environment may be affected as a result of this ritual breach.

In the obsessive rituals, Freud (1913) says that "The main prohibition, the neurosis nucleus, is against touching him, and hence sometimes it is known as contact phobia or delire du toucher" (p. 45). On obsessive neurotic psychic constitution, any fact or situation that leads his thoughts to the incestuous object is as prohibited as the direct physical contact with the object. And he also highlights:

Obsessive prohibitions involve renunciation and restrictions as extensive in the life of those that are subject to it as the taboos prohibitions, but some things can be suspended if certain actions were performed.... These actions... become compulsive or obsessive acts, and there can be no doubt that they are of the same nature of expiation, penance, defensive measures and of purification... The prohibition is loudly conscious, while the persistent desire of touching is unconscious and the subject does not know anything about him. (Freud, 1913, p. 46)

Obsessive acts express the ambivalence present in the neurotic psychic constitution. That is, the desire to touch the incestuous object and the fear to touch it leads the obsessive to an ambivalent attitude regarding the 
given object. The obsessive constantly wants to perform the touch, but at the same time he fears. The obsessive prohibition is displaced from a ritual to another ritual, covering any new objects and objectives that the forbidden desire can adopt, compensating the repressed instinct.

Freud (1913) ensures that the "obsessive acts begin to be as far as possible of anything sexual-magic defenses against evil desires - and it ends being the substitutes of the forbidden sexual act and the closest possible imitations of it" (p. 98). Throughout the obsessive act development, the neurotic is increasingly closer the incestuous act; that is, the prohibited act. In these acts are expressed the ancient romantic and hostile desires that were repressed on the early childhood of this individual. But is should be pointed out that, in all obsessive rituals, the neurotic also expresses the hostile impulse, repressed by a prohibition. This repressed impulse is always related to some specific act and through the displacement, it is presented through some trivial, commonplace activity of the obsessive.

About the hostility present in obsessive rituals, Freud (1913) also points out that "The hostility is then shut up in the screaming... by an excessive intensification of affection" (p. 64). As in the case of the Wolf Man, who at the age of six had a ritual to breath in a ceremonial manner under certain conditions. This patient, each time he made the cross sign, he undertook to inspire deeply or exhale vigorously. Thus, these acts to expire are related with his paternal identification. This identification becomes a source of intense unconscious hostility, reaching the level of a death desire and a guilt feeling that reacted against this hostility.

On the obsessive ceremonials realization, it is also necessary to highlight the importance of "ruminant" thoughts presence on them. In 1917, in the Introductory Conferences, Freud already pointed that the neurotic "undertakes, against his desire, to ruminate thoughts and speculate, as if these were his most important vital problems" (p. 266). It is the presence of ruminant thoughts, impulses (such as that of committing serious crimes) and suicide ideas that lead the neurotic to make certain prohibitions, renunciation, and restrictions. These ideas, thoughts and impulses never come true in acts in reality. Consequently, as he always obtains victory, the escape, and the obsessive precautions, making the obsessive acts very harmless and trivial things, mostly a repetition or ritual elaborations of the individual daily life activities.

After the Introductory Conferences, Freud returns to the obsessive ritual theme in 1926, in the text Inhibitions, Symptoms and Anguish. In this, he points out that "the erotic-anal components sublimation plays an undeniable role in it (in the obsessive symptom)" (1926, p. 117). In other words, with the child psychic development, the sublimation of the old anal eroticism may be present in certain compulsive rituals of washing the hands and in other obsessive symptoms, and these obsessive rituals are nothing more than mere fruits of certain psychic reactive formations.

According to Freud (1926), "The symptoms that are part of this neurosis fit, in general, into two groups, each having an opposite trend. These are prohibitions, precautions and expiation... or, on the contrary, substitutive satisfactions that often appear in symbolic disguise" (p. 114). The obsessive symptoms formation, such as the obsessive rituals, represent a triumph if they can combine the prohibition with satisfaction. Consequently, the obsessive orders and obsessive prohibitions can provide a certain satisfaction to the obsessive ego. The symptoms (such as the obsessive rituals) are the primary products of obsessional neurosis. These are associated with the activities (which are almost automatically performed) just like going to sleep, bathing and dressing. These tend to repetition and waste of time.

The author wants to finish this first theoretical part with the reading of André Green about the obsessional neurosis ritual. In the article "Metapsychology of Obsessional Neurosis", he points out that "the religion-an 
essentially collective phenomenon - would be here reserved in the exercise of only one...” (1967, p. 233). This "only one" refers to the individual and solitary character of obsessive ritual, which realization is excluded from the presence of other people. And in the wise words of Green, "No neurosis gets to do more than providing the subject, through the symptoms, hidden sources of satisfaction" (1967, pp. 235-236).

\section{The Knives Man Case: A Brief Approach on the Hidding Knives Ritual}

Before presenting this case, the author would like to point out that the source of interest for the obsessive ritual study arises from his unique experience with obsessive patients. In the course of psychotherapy care with these neurotic, at a small public health center, in the countryside of the State of São Paulo, the author notices that a large portion of these present some obsessive ceremonial. These always complain of the psychic suffering caused by the daily and compulsive realization of certain ceremonial.

During the care of various obsessive neurotics, the author chose a patient that presented a rich obsessive scenario to develop his master's degree research. So, inspired in Freud and his famous clinic case, the Rats Man, the author decided to name this clinical case of "The Knives Man". This fictitious name arises from his ceremonial act of seeking and hiding knives, although, aside from knives, he also hides other objects like scissors, needles and razor blades.

At the beginning of the psychotherapeutic process, the complaints of Claudio, the Knives Man, was related to his compulsive thoughts of being "hunting knives". This knife "hunting" means seeking and checking if they are hidden, one in each hole of the wall, the couch, and other places, in which he hid them.

In addition to hiding a knife in each hole in the wall, he also hides razor blades, nails and scissors in lower incidence. He hides a nail into each hole in the wall, but the razor blades and the only scissors in the house; he hides in a kitchen drawer, in which his mother keeps the cutlery.

In his complaints, he also reveals that he cannot stand any longer this search for knives to hide them in his father's toolbox and in the drawer of his wardrobe. He said that he checks, several times, if the knives are hidden, so saying: "These rituals are increasingly making me fatigued.... I sleep thinking that there is a knife under my mattress or there in the kitchen.... I think that someone could get hurt, but I know that there is no knife there.... I wake up and go seek for the blessed. I think that if I do not hunt the knife, I can hurt myself, die, or someone of my family...". This someone that may die that he refers, in his later associations, is his father who is described as "rude, angry and who does not take insults from anybody".

This way, Claudio is a young man who comes to psychotherapy marked by his rituals. During the contact, the author could know a bit more of his personal history. He declares that he was a quiet and scared child, never getting involved in fights or arguments. His childhood was market by intestinal problems (constipation crisis), a very present mother and a father always austere. At the age of two and three years, his father worked in the field cutting sugar cane "with a machete". On weekends, the father worked as a cabinetmaker and a barber to earn extra money. Cláudio, at the age of six, presented a constant fear of a possible death of the father figure. And at the age of eight, he began his ritual to hide knives, which lasted throughout his adolescence and current adulthood. Currently, one of his greatest obsessive fears is that the knife, target object of his rituals, comes to poke "his buttocks" if he does not hide it, although he knows that this will never happen.

First of all, for analyzing the ritual of hiding knives, the author would like to return, briefly, to two fundamental points of this patient psychic constitution. These two points are: The first-The constitution of his anal-sadistic phase; and the second-The possible parental identification present in the pre-genital phases. 
The first point, which the author believes to be fundamental for the understanding of this obsessive ritual, results from my understanding of how, probably, occurred his anal-sadistic organization. The author believes that there might have been a certain fixation of libido during this phase; because in his adult genital organization, he presents various obsessive thoughts which suggest its roots at this phase. He assures: "If the knife thought comes, I hide it because I am also afraid that it pokes me in the buttocks...”.

So, in this organization, not only the active, sadistic inclination (of retaining faeces) is striking; but also the passivity that left a big mark, since this passivity was fueled by anal eroticism during his remote childhood. The marks of this passivity are one of the keys to the understanding of the fear that a knife could poke him, because this fear (or desire) is based on his old anal eroticism and the repressed negative Oedipus complex, not quitting the relation with the repressed perversion. And recalling that faeces, baby and penis form an unconscious unity, the author believes that while fearing that a knife poked him, this obsessive idea seems to represent, symbolically, the desire that the paternal sadist penis penetrated him.

The second point necessary for the understanding of this ritual is the possible paternal identification already present in his pre-genital phases. When Claudio was two and three years old, his father worked in the fields cutting sugar cane; and on weekends, he worked with nails in a small joinery of the ranch where they lived, and he also exercised the profession of barber. The author believes that the knives may be representing the father identification, such as the razor blades and the nails too, since they are objects that were used by his father when he worked as a cabinetmaker, country worker and barber during his remote childhood.

The father identification is the central pillar for understanding the emergence of the symptom of hiding knives, at the age of eight. During this ritual, while hiding knives, Cláudio expresses both the identification and all his unconscious hostility to the "father-machete", because of the fact he has interdicted is mother. The identification with the father becomes a source of intense unconscious hostility against him, and the guilt feeling is so striking in the acts of hiding knives that it is also a conscious reaction against this hostility.

At the age of eight, when the act of hiding knives is formed as a protective measure, Cláudio is conscious that he has to hide a knife or someone in his house, like his father, could die. At the beginning of this ritual, the ancient parricide desire is expressed, such desire that was barred by the "wolf-caipora" father during his phallic phase and which is manifested, in a symbolic form, in this symptom.

The beginning of the ritual of hiding knives is quite distant from the forbidden act, because it was an inoffensive, banal act, done in silence, and without anyone knowing. Throughout the adult genital organization, this ritual was increasingly approaching the desired act. In other words, the ritual of hiding knives becomes an action that compensates for the realization of the forbidden desire, because the symbolism present in this ritual denotes the prohibited activity: when hiding the knife, he unconsciously wishes, and through an active form, to obtain a pleasure that a day had been banned. And by putting them dirty of butter in his mother's guava sweet or into her washing basing, the patient "reenacts" the desire to have the mother as an object of pleasure, to penetrate her in a sadistic way.

Claudio presents a diversity of places where he hides these objects. The author believes that, in each place, he finds a form of substitutionary satisfaction of his unconscious desires, because these desires are displaced into rituals of hiding objects in several different places. These various places where he hides the knives and

\footnotetext{
1 The author would like to point out to the reader that both the werewolf and the caipora (hapless person in the figure of a goblin) were two folk figures that Claudio was terrified during his childhood. It is believed in this article that the "wolf-caipora" is a castrating figure displaced from the father figure.
} 
other objects reflect the overdetermination of this symptom.

Not only this overdetermination is striking in this symptom, but also the use of various defense mechanisms. The first mechanism that is present in this ritual, since he was eight years old, and which will dominate his entire adult psychic life, is the reactive formation mechanism. As the repression failed, the act of hiding knives as a reactive formation against the expected evil emerges; that is, against the fear of his father's death. In this ritual so harmless is already being represented, in a symbolic way, the unconscious hate to the father.

At the age of eight, he also reports that he hid a knife under his bed before going to sleep, because he was afraid that someone of this house could die. He assures: "I went to the kitchen, picked up a knife and put it under my mattress.... When I had this thought of knife or death, I used to think or do something else, like hiding knives, to forget this thought.... One thought blocked the other".

In saying that he thought or did something to forget the knife thoughts, the author believes that another defense mechanism present in this ritual is the displacement. And joint to this mechanism are also present the isolation mechanisms of annulment, because when the knife thought came, he displaced this thought and by means of the act of going to the kitchen, he "annuled" and "isolated" the knife thought, taking and hiding a knife under his bed while he slept on it. In the view of the author, this reveals the presence of the desire of being penetrated by the father, since this act denotes a strategy to try to null the homosexual desire, that is, of obtaining a certain passive pleasure of the paternal penis, of being penetrated by him.

Not only these mechanisms are present in these rituals, but also two other characteristics are striking in the act of hiding knives: The first is the ambivalence presence in the psychic dynamic of this patient; and the second is the presence of a death impulse. The author takes this ambivalence idea from the constant obsessive fear of a possible death of his father, since the fear, the fear that his father died is the result of his defense against the unconscious hate directed to the father figure.

As already mentioned, the second striking characteristic in this ceremonial is the manifestation of the death impulse. This means that in this act the destructive impulse is being expressed; because, in addition to manifesting all the hostility to his father, he also expresses his destructiveness directed to the external environment.

That is, the knife is a symbolic object that represents, in a contained manner, all destructiveness addressed to the father and to the outside world, but the knife also represents the whole aggressiveness one day introjected in this father, being this knife a representative of the aggressive, sadistic penis introjected by Claudio in his childhood, striking the passage of his passivity (of receiving this penis) for the masculinity, leaving him, forever, handed over the ghost of homosexuality. For this reason, the fear of knives also referred to the former homosexual desires of his remote childhood; since the incorporation of this sadistic paternal attribute (currently symbolized by knives) allowed the (dis)pleasure of the identification to his father.

And as the complaint about these rituals permeated our entire clinical contact, the author believes that another data still needs to be highlighted in this presentation. Why does he feel so guilt when performing these rituals?

The author believes he finds the explanations for the guilt feeling in the possible existence of unconscious aggressiveness directed to the father figure. In other words, this guilt is linked, possibly, to the manifestation of the destructive impulses in the act of hiding knives.

About this symptom, Claudio also ensures that, after arguing with the father, he passes by each hole 
checking the knives. In order to relieve himself from the guilt, he gets a knife and hides it. He reports: "when I hide it, it seems that the guilt disappears, strange...". While repeating his ceremonial acts, the guilt becomes a vicious circle in the act of hiding knives: at the same time that he relieves from it, it becomes increasingly stronger.

The author compares this ritual of hiding knives to a primitive ritual, because each time he sticks a knife in some hole, each time that he symbolically "kills" this dreaded father (who represented an obstacle to his sexual desires), he symbolically satisfies his unconscious hate. But this supposed parricide, that is, this father that symbolically was dead, returns stronger each time due to the old identification of Claudio with him. Consequently, the guilt feeling becomes increasingly intense, and the only possible way for him relieving himself from guilty, as he himself said, is resuming again this act of hiding knives. And, when returning to perform the ritual, he lives what he calls "hell here on Earth.... This is a hell; I am paying for my sins still alive...".

Beyond the guilt feeling, Claudio presents a very striking animism in his thoughts. He has always believed in mental telepathy, telekinesis, extraterrestrial life, witchcraft and scorcery since his childhood. Another topic that most interests him is related to funeral affairs. During his adolescence, he had a ritual of going to the cemetery and counting the dates that his father's relatives had died. This ritual can be regarded as a manifestation of the parricide desire that one day was present in his infant genital organization. This means that the attitude of going to the cemetery expresses, in a symbolic way, the desire of his father death that was present in the ritual of counting and recounting the numbers of the Batistas' family tombs (fictional surname of this patient father). On the other hand, the act of counting and recounting is a symbolic act of trying to pay the eternal debt with him, for the fact of having desired his death and also of his wife.

The author remembers the first session he reported this ritual and the association that such memory triggered. This consisted of: "You know, cemetery reminds me death, deceased, dead man...". Thus, in his fantasies, Claudio is still stuck to the theme of death. It is his father death, the great figure responsible for his castration, which he attempts to deceive by employing various strategies during his rituals. As a sacred act, he firmly believes that in his rituals, on the strength of his thoughts, in the power and in the realization of his acts of hiding knives, making these his particular region.

On the completion of this succinct clinical interpretation, the author would like to point out that the ritual of hiding knives highlights the relationship of a "son-knife" with the "father-machete". In this relation, the paternal identification is revealed since the emergence of Claudio's ritual at the age of eight. During his childhood, while sleeping, he did not have to go around the bedroom with a chair to climb up and kiss religious images hanging on the wall, like the Wolf Man, but he needed to hide a small knife in his bedroom. Currently, during his ceremonial acts, the father is still the big figure that permeates the intricacies of these symptoms, sustained by the (unconscious) hate of this son. Thus, these rituals point to the castrator father figure, which is responsible for the repression of his oedipal desires, causing Claudio to occupy a place never expected by him before. It is about this place that he complains so much during the sessions: the place of a desiring subject, imprisoned by his own repressed desires during his rituals.

\section{Conclusion}

On the completion of this article, the author wants to point out that studying the obsessive ritual does not require only the approach of a ceremony with its repetitive acts. Studying it requires an understanding of the 
entire psychic dynamic of any obsessive presenting some kind of ceremonial.

In short, this article, by means of a case taken from the care provided at a public health center, reveals that the obsessive ritual, this individual and private religion of the neurotic, is presented through trivial activities of everyday life. In every obsessive act, both the destructive impulses, and a desire represented by a counterdesire are being expressed; that is, it is the ambivalence (of desire and fear, love and hate) that surrounds the obsessive ritual execution. And despite the intense psychic suffering, the ritual is approaching more and more of satisfaction and the originally prohibited activity (and eternally desired) of the obsessive.

\section{References}

Freud, S. (1895/1996). Obsessions and phobias: Its psychic mechanism and its etiology. ESB, I. Rio de Janeiro: Imago.

Freud, S. (1896/1996). New comments on the defense neuropsychosis. ESB, III. Rio de Janeiro: Imago.

Freud, S. (1897/1996). Letter 69. ESB, I. Rio de Janeiro: Imago.

Freud, S. (1907/1996). Obsessive acts and religious practices. ESB, IX. Rio de Janeiro: Imago.

Freud, S. (1909/1996). Notes on a case of obsessional neurosis. ESB, X. Rio de Janeiro: Imago.

Freud, S. (1913/1996). Totem and taboo. ESB, XIII. Rio de Janeiro: Imago.

Freud, S. (1917/1996). Conference XVII-The sense of symptom. ESB, XVI. Rio de Janeiro: Imago.

Freud, S. (1918/1996). History of an infantile neurosis. ESB, XVII. Rio de Janeiro: Imago.

Freud, S. (1926/1996). Inhibitions, symptoms and anguish. ESB, XX. Rio de Janeiro: Imago.

Green, A. (1967). Metapsychology of obsessional neurosis. In Psychonévrose obsessionnelle et obsessions (1967). Paris: Encyclopédie médico-chirurgicale. Translation of Saulo Krieger. 